M. Jametti, T. von Ungern-Sternberg

Hurricane insurance in Florida

Quaderno N. 09-05

Decanato della Facoltà di Scienze economiche Via G. Buffi, $13 \mathrm{CH}-6900$ Lugano 


\title{
Hurricane Insurance in Florida
}

\author{
Mario Jametti* \\ University of Lugano, Switzerland, \\ York University, Canada, and \\ CESifo
}

\author{
Thomas von Ungern-Sternberg** \\ Faculty of Business and Economics, \\ University of Lausanne, Switzerland, \\ and CESifo
}

\begin{abstract}
This paper studies the evolution of hurricane insurance in Florida over the last decades. Hurricanes (and other natural catastrophes) are typically referred to as "uninsurable" risks. The more exposed property owners find it difficult to obtain insurance cover from the private market and/or can do so only at premiums that substantially exceed their expected claims costs. The state of Florida has reacted to the incapacity of the private sector to insure hurricane risks at reasonable premium levels with the creation of Citizens Property Insurance Corporation (an insurer of last resort) and the Florida Hurricane Catastrophe Fund. Their existence has resulted in substantial premium reductions for the Florida property owners. Both institutions have the possibility of spreading the costs of a major hurricane over a (very) large number of policy holders through after the event compulsory assessments. The risk borne by each individual property owner is thus reasonably small, with substantial benefits for consumers as a group. Looking forward the challenge to the policy maker will be to fine-tune the operation (premium structure) of these two institutions so as to increase their political acceptance. To this end it will be necessary to limit the implicit subsidy of the "bad risks" through the "good risks".
\end{abstract}

Key Words: Hurricane, Catastrophe Insurance, Regulation, Market Failure, Florida JEL: $\quad$ G22, L51, L33

* Institute for Microeconomics and Public Economics (MecoP), University of Lugano, Via G. Buffi 6, 6904 Lugano, Switzerland; e-mail: mario.jametti@lu.unisi.ch.

** $\quad$ Corresponding author: Ecole des HEC, Université de Lausanne, 1015 Lausanne, Switzerland; e-mail: Thomas.vonUngern-Sternberg@unil.ch. 
Florida is the State in the US which is the most subject to being hit by hurricanes, and resulting damage, particularly over the last 2 decades, has been extensive (and expensive). [Andrew (1992), Charley, Frances, Ivan and Jeanne (2004), Wilma and Katrina (2005)].

The inability or unwillingness of private insurance companies to offer hurricane cover to property owners in the more exposed areas of Florida at premiums (and other insurance conditions) that are considered affordable (by the property owners and/or the politicians), has led to various types of state intervention (which will be discussed below). In 2008 the Senate of Florida has set up a Task Force to study how the regulation of the property insurance market in Florida should evolve. The report of the Task Force is due in the course of 2009.

In March 2008 the Wharton Risk Management and Decision Process Center published an ambitious and voluminous (close to 400 pages) book entitled "Managing Large Scale Risks in a New Era of Catastrophes". ${ }^{1}$ Its declared purpose is to provide "a series of in-depth analyses of the efficiency and equity of current disaster insurance markets" and "the impact of statebased regulations on the insurance protection and the loss distributions among different stake holders". In the Preface and Executive Summary the authors write "Now is the time to develop and implement economically sound policies and strategies for managing the risk and consequences of future disasters” (Wharton, 2008, p.i).

Unfortunately, the focus of the study is quite narrow when it comes to the kind of economic policies it tends to advocate. The most obvious symptom of this is the fact that certain types of state intervention which have proved their worth in several European countries for decades (and sometimes centuries) are not even mentioned in the study. The best known examples in this respect are the local monopoly property insurance providers in large parts of Switzerland, the monopoly state reinsurance company for catastrophes in Spain (the Consorcio de Compensacion de Seguros, created at the end of the civil war), the state guaranteed reinsurer in France (the Caisse Centrale de Reassurance, created in the 1970s) etc ${ }^{2}$. In a follow-up paper we plan to study to what extent the experiences in these (and other) European countries might be of relevance for the US policy maker.

Even if one concentrates only on the institutional framework as it currently exists in the US, the focus of the Wharton study is still quite narrow. The authors have a sharp eye when it comes to identifying potential drawbacks of state interventions in the catastrophe insurance market. At the same time they tend to gloss over the (obvious) shortcomings of competitive markets when it comes to providing satisfactory (and cost efficient) insurance solutions to property owners with an above average exposure to hurricanes (and other natural catastrophes).

Implementing the policy recommendations of the Wharton study in Florida might well increase the importance of the private insurance sector when it comes to providing hurricane insurance in Florida. There is, however, a good chance that it would do so only at a very high

$1 \quad$ In 2009 the report was published by MIT Press as “At War with the Weather : Managing Large-Scale Risks in a New Era of Catastrophes”.

2 Thomas von Ungern-Sternberg's book “Efficient Monopolies: The Limits of Competition in the European Property Insurance Market “, Oxford University Press (2004), summarizes the experiences of these and other countries in some depth. 
cost to the property owners; and it would do so at a time when the financial situation of many households in Florida is already severely strained.

The need for public sector intervention in natural disaster insurance markets has been discussed as early as Kunreuther (1974). Jaffee and Russell (1997) argue that the characteristics of natural disaster events "do not seem sufficient to cause failure of private markets” (p. 206). For them the key issue is the incompleteness of financial markets. Jametti and von Ungern-Sternberg (2005) show, for the case of Switzerland, that similar levels of insurance can be provided more cost-efficiently by public providers. Several authors have proposed systems of public-private partnerships. Gollier (2005) discusses several aspects of free-market inefficiencies (e.g. transaction costs, limited liability and asymmetric information) in the context of disaster insurance, advocating that the government play the role of insurer of last resort. Similarly, Kunreuther and Pauly (2006) analyzing assistance to victims of Hurricane Kathrine propose a mandatory comprehensive disaster insurance, with public sector participation in reinsurance, subsidies for low income households and prevention. $^{3}$

The purpose of this paper is to briefly summarize the evolution of the regulatory framework for hurricane insurance in Florida over the last 40 years, and provide a more in-depth analysis of the impact the regulatory intervention has had on the availability and cost of insurance. In doing so, we correct some of the major oversights in the Wharton (2008) study. We hope our analysis can assist the Florida legislator in the delicate task it is facing: adapt the current regulatory framework in such a way that the property owners continue to be able to obtain insurance cover at affordable premiums, while at the same time limiting the strain put on the State's finances when the next major hurricane strikes (as it inevitably will).

The rest of this paper is structured as follows: Section I briefly summarizes the major milestones in the evolution of the Florida hurricane insurance market. Section II discusses the impact of the current institutional framework on the main stake holders. Section III ends with some concluding remarks.

\section{Main developments in the Florida hurricane insurance market}

\section{A) Conceptual background}

There are three factors which put hurricanes, like several other kinds of natural catastrophes, in the category of risk that is typically referred to as "uninsurable"4.

a) Damages may occur infrequently but they can be substantial.

b) Damages are typically concentrated in one geographic region (and most buildings in that region are affected to some extent).

c) It is hard to objectively estimate the expected damage cost.

\footnotetext{
3 One issue that is frequently neglected in these public-private partnerships is the issue of risk-selection. Jametti and von Ungern-Sternberg (2009) discuss risk selection in several public-private partnership, among them France and Florida.

$4 \quad$ See e.g. Jaffee and Russell (1997).
} 
The term "uninsurable" was coined by the insurance industry itself. It refers to the fact that private insurance companies usually try to avoid insuring risks of this kind or do so only at premiums that are substantially higher than expected claims costs.

From a conceptual perspective, there are two kinds of mechanisms underlying insurance: risk pooling and risk spreading.

Risk pooling refers to the idea that the cost of risk can be substantially reduced if a large number of independently distributed risks is pooled. Risk pooling does not work well in the case of hurricanes because the risks in any given geographic area are not independently distributed (i.e. they are highly correlated). ${ }^{5}$

Risk spreading refers to the idea that the cost of risk can be reduced if the risk can be spread over a sufficiently large number of individuals each holding a small portion of the risk. As we shall discuss in more detail later on, in practice the mechanism of risk spreading does not by itself seem sufficient to ensure a well functioning competitive market for hurricane insurance. One of the major advantages of state interventions in this market is the fact that the State can spread the risks it takes over a very large number of individuals. ${ }^{6}$

\section{B) The evolution of hurricane insurance in Florida}

Historically, the first attempt by the State of Florida to improve on the performance of the private insurance industry was the creation of the "Florida Windstorm Underwriting Association" (FWUA) in 1970, to cover wind (i.e. hurricane) risks in the Florida Keys. The FWUA has since expanded its activities to 29 of the 35 coastal counties in Florida. Its official purpose was to "provide Florida citizens adequate wind and hail coverage, when it is not available in the insurance market place, and pay insured claims when losses occur". The FWUA like its successor organisations (see below) all suffer from the same type of ambiguity: on the one hand the legislator wishes to provide affordable insurance to those customers unable to obtain such (i.e. affordable) cover from the private insurance sector. On the other hand the law clearly mandated the FWUA to "charge rates sufficient to cover losses...”. The uncertainty surrounding the extent and frequency of hurricane losses in the future is substantial. It is thus open to some considerable freedom of interpretation if and to what extent the FWUA might at any point be deviating from its legal mandate.

The two most obvious potential explanations why the legislator might want to intervene in the hurricane insurance market are that:

a) he believes the private insurance industry to (substantially) overestimate the expected cost of hurricane damage, or

b) he considers the mark-up over and above expected claims costs the private insurance industry charges to bear this risk to be so high, that a more cost efficient alternative in the form of state-supplied insurance is financially viable.

\footnotetext{
$5 \quad$ Pollner (2001) extensively discusses the issues of risk pooling in natural disasters.

$6 \quad$ Freeman et al. (2003) illustrate the difficulty to spread risk effectively for the case of developing countries,.
} 
Given the recent experience in Florida there is a third consideration that must be born in mind.

c) If the private insurance companies charge the customers who are likely to suffer a major hurricane damage (with a low probability) what they consider to be "adequate" insurance premiums, they would be able to accumulate substantial reserves if there are several years in a row without major hurricanes. Some insurance companies might then be tempted to pay out these accumulated profits in the form of bonuses, dividends or share buy-backs. Should a major hurricane strike they would not then have sufficient reserves to cover their claims costs.

\section{a. Hurricane Andrew (1992)}

In 1992 Hurricane Andrew, with an estimated total damage of the order of US\$ 25 billion (US\$ 16 billion of which was insured) left the insurance industry in Florida with substantial losses. This had two major consequences:

a) 11 small insurance companies with insufficient reserves and/or reinsurance cover went bankrupt, leaving the Florida Insurance Guaranty Association (and thus ultimately the other insurance companies of Florida and their customers) to foot the bill.

b) Second, the remaining insurers took a new critical look at the exposure they were facing and tried to (drastically) reduce the number of policies and the extent of cover they were providing.

To prevent the insurance companies from leaving the sinking ship (and the house owners with risks that could financially ruin them for the rest of their lives) the State of Florida took several measures:

1. It passed an urgent law limiting the extent of policy cancellations to $5 \%$ per annum maximum at the state level and $10 \%$ per annum maximum at the county level, i.e. it tried to force the private insurance industry to provide cover in Florida over and above the level they would choose voluntarily. This measure was accompanied by restrictive rules as to the size of the premium increases they could impose on their customers.

2. The possibilities of forcing private insurance companies to insure risks they no longer want to hold are of course limited. To make insuring hurricane risks in Florida a financially more attractive prospect, the State in 1993 (i.e. just one year after Hurricane Andrew) created the Florida Hurricane Catastrophe Fund (FHCF). Its purpose was to allow the individual insurance companies to reinsure part of their hurricane risk portfolio with the State. The reinsurance conditions offered by the state were substantially more attractive than those available on the private reinsurance market (see below).

In spite of these measures, the major insurance companies' active in Florida reduced their exposure substantially. The largest insurer "State Farm Group" reduced its market share from $30.5 \%$ in 1992 to $20.1 \%$ in the year $2000 .^{7}$ The second largest "Allstate Insurance Group" reduced its market share from $20.4 \%$ in 1992 to $11.2 \%$ in the year $2000 .^{8}$ Even these massive

$7 \quad$ It is interesting to note that in State Farm has left the Floridian market altogether by 2009.

$8 \quad$ Wharton (2008) p.69. 
reductions (the two groups reduced their customer base by one third and one half respectively) do not fully reflect the extent of turmoil on the market. The aggregate data do not indicate the extent to which these reductions in the customer base were concentrated on the high risk areas.

3. To fill the gap left by the private insurance industry, the State in December 1992 (i.e. just months after Hurricane Andrew) created the "Florida Residential Property and Casualty Joint Underwriting Association” (JUA). Its mission was to provide residential property insurance coverage "for applicants who are in good faith entitled, but are unable, to procure insurance through the voluntary market."9

As a result of the bankruptcies and the private insurance companies' drive to reduce their exposure on the Florida market, the size of both the FWUA and the JUA exploded in the aftermath of Hurricane Andrew. By 1996 their joint total exposure had risen to over \$180 billion.

When Florida was not struck by a major hurricane for some years, insurance companies became more optimistic once more and were willing to take back large parts of the JUA portfolio. Its market fell from 950 thousand policies with a total exposure of US\$ 100 billion in 1996 to a mere 60 thousand policies with a total exposure of just below 10 billion US\$ in the year 2000 .

\section{b. $\quad$ The 2004-2005 hurricane seasons}

From a media perspective the 2004 hurricane season was less spectacular than Hurricane Andrew, but it left a deep impression on the insurance industry. There are two reasons for this.

First, this was the first time that Florida was struck by a series of violent hurricanes in the same year. While hurricanes Charley, Frances, Ivan and Jeanne individually caused nowhere near the damage left by Andrew, all four of them together still cost the insurers more than 25 billion US\$ in Florida alone. They became aware that they were not just menaced by "a big one" but also the possibility that several medium size events might leave deep scars in their balance sheets in any given year.

Second, it had always been assumed that the worst hurricanes would strike from the Atlantic coast. The 2004 hurricanes did not follow this pattern. They came from both the Atlantic and the Gulf of Mexico. The insurance industry had to radically redraw its risk maps.

When Hurricanes Wilma and Katrina (both category 5) struck just one year later, it became even more obvious that any historical evidence one had about the frequency of hurricanes should be used with great circumspection at best. The indications that the hurricane danger in Florida might have increased massively as a result of climate change (or other factors?) were too strong to be ignored, and the insurance companies reacted by once again massively reducing their exposure and increasing their premiums. The average premium doubled from $723 \$$ in 2002 to $1465 \$$ in 2007. The premium increase would have been even more substantial had not the FHCF once again increased the reinsurance cover it offered. 


\section{C) The Florida Hurricane Catastrophe Fund}

The basic structure of the FHCF is as follows: Participation in the Fund is compulsory for all insurance companies writing property insurance in Florida with a total exposure of more than 10 million dollars. In each year the insurance companies must cover the first part of their total claims payments themselves. If their claims payments exceed this minimum amount the FHCF will bear a fraction of these additional claims payments. The insurance companies can choose (up-front) what part of these additional claims they want to reinsure with the FHCF. They are offered three possible levels of reinsurance cover; $45 \%, 75 \%$ or $90 \%$. Essentially what the FHCF is offering the insurance companies is a standard non-proportional reinsurance contract with an excess the companies have to bear themselves.

One might expect that the compulsory nature of the Fund is to facilitate an indirect subsidy of the "bad risks" through the "good risks". This is, however, somewhat at odds with the provision that the independent expert charged with calculating the reimbursement (i.e. reinsurance) premiums should see that these are "actuarially indicated" (i.e. fair), taking into account location (zip-code), type of construction, type of coverage etc ${ }^{10}$. If the premiums were actuarially fair, the system should not have any major redistribution effect. However, if this were the case, why make participation in the system compulsory?

The total coverage provided by the FHCF was capped at $\$ 15$ billion per year. This upper limit was increased to $\$ 28$ billion in 2006, in the aftermath of the catastrophic 2004-2005 hurricane seasons, when reinsurance cover on the traditional market became both more difficult and more expensive to obtain.

Should the FHCF not have sufficient funds to cover its obligations, it has the possibility of raising money on the financial markets by issuing "revenue bonds". To repay these it may "levy, by order, an emergency assessment on direct premiums for all property and casuality lines of business in Florida." 11 The annual assessments may not exceed $10 \%$ of premium income. The Fund further has the possibility to directly increase its income through an emergency assessment in case of large losses in any given calendar year. This surcharge may not exceed $6 \%$ of the premium income.

The financial markets in the US have practically dried up over the last year, and the US (like the rest of the world) is entering a major recession. As a result there is currently vast uncertainty whether the FHCF would in fact be able to rapidly raise the funds (sell the bonds) necessary to cover its obligations if Florida were to experience another bad hurricane season in the next few years.

\section{D) The Citizens Property Insurance Corporation}

The major difference between the FWU (created in 1970) and the JUA (created as an urgent measure in the aftermath of Hurricane Andrew) was the fact that the first offered only wind cover while the second could supply multi-peril property insurance. There was, however, no good reason to maintain these two institutions side by side. They were merged in 2002 to create the Citizens Property Insurance Corporation (Citizens). Like its predecessors, its official purpose was to provide property insurance to those house owners who could not

$10 \quad$ Florida Statutes 627.6628(3)(b).

$11 \quad$ Florida Statutes 215.555 (FHCF). 
obtain cover at an "affordable" premium from the private sector. The term affordable can of course be interpreted in different ways. Given the political pressure to prevent property insurance premiums from rising too fast, Citizens has in the last few years had the political backing necessary to allow it to interpret this mandate quite largely. As a result, it is currently the largest property insurer in Florida.

Citizens subdivides it total customer base into three categories, "Personal Line Accounts (PLA)", "Commercial Line Accounts (CLA)" (both residential and non-residential) and ""High Risk Accounts (HRA)” (located in counties with a high hurricane risk).

The evolution of its "Direct Written Premiums" for each category is summarized in the Table below.

\section{Citizens “direct written premiums” by type of account (US\$ million)}

\begin{tabular}{|c|c|c|c|c|c|}
\hline Account & 2003 & 2004 & 2005 & 2006 & 2007 \\
\hline HRA & 586 & 714 & 881 & 1'275 & 1'311 \\
\hline PLA & 515 & 635 & 669 & 1'622 & 1'840 \\
\hline CLA & 70 & 53 & 59 & 505 & 567 \\
\hline Total & 1'171 & $1 ' 402$ & 1'609 & 3'400 & $3 ' 718$ \\
\hline
\end{tabular}

One notes that Citizens' customer base literally exploded between the years 2005 and 2006, i.e. in the aftermath of the 2004-2005 hurricane seasons. The reasons for this development will be discussed further on.

Currently Citizens' premium volume of 3.7 billion US\$ comes from 1.4 million contracts with a total exposure of more than 500 billion US\$. It estimates its net exposure from a 100 year event to be of the order of 25 billion US\$ (for all three categories combined).

One of the specificities of Citizens is that it can cover its deficits in each of the above mentioned product lines by imposing a compulsory surcharge (an assessment) on existing insurance contracts. The modalities of these assessments have been modified in May 2008. In the past, the first regular assessment concerned only Citizens own customers, and the assessment could not exceed $10 \%$ of the premium. As of 2009 this rate has been increased to $15 \%$.

If this amount was not sufficient to cover Citizens' deficit, it could levy a further surcharge on all property insurance policies in Florida. The maximum amount of this assessment was either $10 \%$ of the premium income or $10 \%$ of Citizens deficit, whichever was greater. As of 2009 this rate has been decreased to $6 \%$.

Any remaining deficit incurred by Citizens can be financed through issue of a "revenue bond". This will then be repaid through multi-year emergency assessments on all property insurance policies. The maximum amount of these emergency assessments is $10 \%$ of the premium income or Citizens' outstanding deficit, whichever is greater.

Citizens thus has a possibility which is not available to other "voluntary" insurance companies. It can finance its potential deficits by levying a surcharge on its "competitors" customers. It is easy to understand, why the voluntary insurance companies in Florida have some misgivings about this situation. It creates a very un-level competitive playing field. 
While the private insurance companies have to calculate their premiums in such a way as to cover their expected damage cost, Citizens could potentially deliberately charge lower premium rates, substantially increase its market share and, in case of a major claims event, have a (large) part of its claims cost be financed by its "competitors" customers. The changes in the assessment modalities outlined above are clearly designed to shift a larger part of the burden of these assessments onto Citizens' own customers.

The asymmetric situation between Citizens and its "competitors"" explains why the legislator tried to build in a number of safeguards, to prevent Citizens from exerting competitive pressure on the market.

For both the Personal Line and the Commercial Line insurance, a property owner can become a Citizens customer only if the best offer he has obtained from the voluntary market is at least 15\% higher than Citizens' standard rate for this kind of risk.

Voluntary insurance companies are provided financial incentives to buy up parts of Citizens customer portfolio. This financial incentive was initially 100 US\$ per policy. Of course, a one shot payment of this type potentially creates an incentive to buy up the policy, provide the customer insurance cover for one year, and then cancel the policy. It is presumably for this reason, that the 100 US\$ incentive bonus is now pro-rated over a period of 5 years.

Citizens is also mandated to enter into "quota share" agreements with the voluntary insurers: If a private insurance company is willing to bear a specified percentage of the risk of some part of the portfolio (or an individual customer) it obtains the same percentage of Citizens premium income.

Initially, Citizens was not permitted to offer insurance cover for properties with a value of more than 1 million US\$. The purpose of this provision was to prevent rich individuals from building houses in high risk areas and then have the cost of reconstruction after a hurricane borne by the general public. The 1 million US\$ limit was recently increased to 2 million US\$ presumably to take into account the massive increase in Florida's property prices. Of course, this measure has turned out to be totally misplaced. The subprime loan crisis and the burst of the speculative bubble on the US housing market have brought Florida property prices back to more reasonable levels.

According to Citizens' Statutes, "rates for coverage provided by the corporation shall be actuarially sound..."12 Nevertheless the rate increases Citizens tried to impose in 2006, presumably in order to meet just this requirement, were considered excessive by the legislator and repealed. A rate freeze was decreed till 2010.

"Beginning on July 15, 2009, and each year thereafter, the corporation must make a recommended actuarially sound rate filing for each personal and commercial line of business it writes, to be effective no earlier than January 1, 2010". ${ }^{13}$

This combination of an institutionalised rate freeze combined with the reiteration of the request for "actuarially sound" rates is probably as good an indication as any of Citizens ambiguous position.

\footnotetext{
$12 \quad$ Florida Statute 627.351(6)(d)
}

13 Florida Statutes 627.351(6). 
In 2006 Citizens had direct written premiums of US\$ 3.4 billion, its largest voluntary competitor "State Farm Group" had US\$1.4 billion. Given these orders of magnitude, it is hard to deny that Citizens has become a major market force in Florida. One could of course decide to still call it an "insurer of last resort", but if so then for a large fraction of the total population. A task force has been set up to study how and to what extent this development can be reversed. The report is due in February 2009.

\section{Analysis}

Both Citizens and the FHCF intensify competition on the Florida property (re)insurance market (especially for bad risks) and thus exert downward pressure on property (re)insurance premiums. One of the main reasons they can do this is because (by law) they have a possibility private (re)insurance companies do not have: They can recuperate their accumulated losses by levying a surcharge (an assessment) on all property insurance contracts.

The same point can be reformulated as follows: In a competitive environment, the private (re)insurance sector does not have the power to after the event increase its premiums to cover potential losses. Such losses thus have to be borne by their shareholders. The State can levy an assessment on the insurance customers, and thus cover its deficits ex post. The State can do this, because it has captive customers. The individual private (re)insurer cannot do this, because it does not have captive customers.

To understand in more detail the effects this may have, let us start off by concentrating on the FHCF, and then in a second step turn to Citizens.

\section{A) Intertemporal substitution}

One way of interpreting the difference in approach of a private and a public supplier of reinsurance is from the perspective of intertemporal substitution. If the private reinsurance sector charges excessively high premiums because it overestimates the danger of a hurricane, this means that (ex post) the insurance companies and their customers (the property owners) have paid too much. If the FHCF charges insufficient reinsurance premiums because it underestimates the danger of a hurricane, this means that the future property owners have to pay too much (in the form of assessments to cover the deficits of the past).

Of course, and this is an important point, these "future property owners" are by and large the same as the property owners who benefited from the low premiums in the first case.

To summarise, in the one case we have (re)insurance companies who have accumulated reserves, i.e. some house owners who leave the region have paid insurance premiums that are "ex post" higher than the damage that occurred. These reserves are then (in theory) available to pay for the claims of the next generation. In summary, the previous generation pays for the next generation

In the other case we have a state reinsurance company who can tax (assess) future house owners to recoup the deficits it has accumulated. The customers who have just recently entered the market (bought a property) thus have to pay for the previous generation. 


\section{B) Cross-sectional redistribution}

As mentioned, the FHCF's premium structure is, in principle, supposed to be actuarially fair. If this were in fact the case, one should observe that insurance companies with very different risk profiles purchase the same amount of reinsurance cover from the FHCF. In practice this does not seem to be the case. Over $40 \%$ of the FHCF's business is with Citizens. This is strong evidence that the FHCF's reinsurance conditions are particularly attractive for insurers with a high proportion of bad risk customers.

There are thus two mechanisms by which the FHCF leads to an indirect subsidy of the "bad risks" by the "good risks". First the reinsurance premiums of the bad risk are not in fact sufficient to cover their expected costs, i.e. they are subsidised by the reinsurance premiums of the good risks. And second, when an assessment becomes necessary, the good risks further subsidise the bad risks. The assessments are proportional to the premiums and these, as we have just seen do not fully reflect the true underlying risk.

\section{C) Property rights}

The FHCF as a public reinsurance company does not have a profit motive. Any profits it makes or reserves it accumulates by Statute have to stay in the Fund and are thus available for future claims payments.

The situation is different in the case of a private reinsurance company. As a profit making enterprise its role is to generate profits for its share holders and pay these out in the form of dividends and/or share buy-backs. The fact that a group of reinsurance customers may have paid reinsurance premiums but has not had any claims payments, does not mean that this money is still around for future claims payments and will be used to reduce future reinsurance premiums. To the contrary: if there are good reasons to believe that the hurricane risk in a given geographic will increase, the reinsurance companies will increase their premiums, even if there have been no major claims in the preceding years.

Alternatively formulated, with a state reinsurance supplier, the customers know that on average the premiums they pay will, in the long run, be equal to their effective claims payouts. With a private reinsurance sector, the premiums paid in may be substantially higher or substantially lower than the effective payout even for long periods of time.

This problem will be particularly important if the probability of a major event occurring is quite low. For example, an event with an occurrence probability of 1 in 100 has a 26\% chance of never occurring in any 30 year period.

The above analysis of the private reinsurance market is somewhat mitigated (but not invalidated) by the introduction of financial capacity constraints. These modify the analysis as follows: when reinsurers have suffered large losses, their reserves are low and they have to rely more on financial markets to obtain funds. They price this increase in the cost of capital into their insurance premium. As a result, an increase in past losses will lead to an increase in future reinsurance premiums. This "capacity constraint theory" thus creates a link between past losses and future reinsurance premiums, even if the underlying probabilities have not changed. 


\section{D) The expected cost of reinsurance}

There may be substantial differences in the expected cost of reinsurance between public reinsurance and private reinsurance companies. In the case of the FHCF the main danger would currently seem to be that the FHCF might tend to charge excessively low reinsurance premiums, thus imposing a potential burden on future customers.

In the case of the private reinsurance market the situation is different. Since private reinsurance companies cannot in principle cover their deficits with after-the-event premium increases, they have to calculate their reinsurance premiums with a forward looking perspective.

As mentioned above, the Wharton study (2008) has emphasised that reinsurance companies (just like primary insurers) cannot satisfy themselves with simply charging actuarially fair premiums. In particular, the study points out that they have to take into account the impact of an increase in the risks they take on their cost of capital. To put the point simply: if taking on an additional risk reduces the credit rating of a reinsurer, this increases the average cost of capital. The (re)insurer has to adequately take this increase in the average cost of capital into account when setting the price it charges for this additional risk. "For truly extreme risks, the resulting premium can be as much as 5 to 10 times higher than the expected loss, so as to provide investors with a fair return on equity...”"14

The Wharton study further provides empirical evidence that reinsurance companies do not like parameter uncertainty, i.e. reinsurance premiums increase substantially when they are faced with such uncertainty. "A recent survey of actuaries and underwriters by the Wharton Risk Center revealed that insurers would charge 25 percent higher premiums for ambiguous risks than for risks with probabilities that were well specified." ${ }^{25}$

One could reasonably argue that (the danger of) global warming has substantially increased the parameter uncertainty surrounding many types of natural catastrophes including hurricanes. Parameter uncertainty should thus be of some relevance for hurricane insurance.

Both of the above factors taken together would indicate that even in a competitive reinsurance market, the premiums for hurricane insurance may well be considerably higher than the expected claims costs. This raises a simple question: What is the better solution for the primary insurance customers? Pay premiums that are (too) low to a public reinsurance company, and bear the risk of having to pay assessments later on if the public reinsurer has insufficient funds? Or pay private reinsurance companies premiums that are a multiple of the expected claims costs, in return for not running the danger of such ex post assessments.

The answer to this question will of course depend on the degree of risk spreading the public reinsurance company can operate. This pool is fortunately quite large. There are 5.7 million homeowner policies in Florida. Any assessment levied by the FHCF will thus be spread over a large number of policies, or alternatively formulated, the cost per policy is relatively low. One might of course argue that even so the cost of risk born by the individual household is still too large. If one believed this to be the case, the FHCF should try to purchase an adequate amount of reinsurance on the private market.

\footnotetext{
$14 \quad$ Wharton (2008) p.vii.
}

15 Wharton (2008) p.vii. 
One of the major criticisms one might make of the Wharton study is that it completely fails to address these issues. It produces good arguments why one should expect private sector (re)insurance premiums for hurricanes to substantially exceed expected claims cost. It does not, however, go the next step and address the question, to what extent the cost to the population (the customers) might be lowered by appropriate state interventions. Potentially this is due to the fact that (some of) the authors have a strong affinity to the private insurance sector.

To summarize, the major advantages of the FHCF are that it does not need to build up the same kind of reserves a private reinsurance company needs and it has a large pool of (captive) customers over which it can spread any deficits it might have. Furthermore, being a non-profit organisation it does not have to worry about obtaining an "adequate" return on capital. These elements should allow it to provide reinsurance cover at much lower premiums than the private market. By doing so it reduces the part of the risk that has to be borne by the private market, i.e. the private reinsurance market will take on this residual risk at a (much) lower cost (over and above the expected claims costs) it would otherwise charge. The existence of the FHCF thus benefits the Florida property owners in two ways: a) directly by providing low cost reinsurance and b) indirectly by reducing the reinsurance premiums charged on the commercial market.

The political support for the FHCF would presumably be much greater were it not for the fact that its current premium structure still has substantial redistributive effects. The "low risk" customers (inland) subsidise the high risk customers (on the beach). It would be most regrettable if this redistributive effect were to ultimately lead to a situation where the institution as a whole is menaced. A more balanced (actuarially sound) premium structure would permit the FHCF to continue performing its major useful role for the Florida property owners (lower the cost of reinsurance and thus the insurance premiums) while at the same time significantly reducing its political vulnerability.

\section{E) Citizens}

Most of the arguments set out above for the FHCF are of course, mutatis mutandis, also valid for Citizens. It also has the ability to cover its deficits through ex post assessments. There is, however, one important difference. The FHCF offers low cost reinsurance to all Florida insurance companies (and indeed taking out such reinsurance is compulsory). The group of individuals covering the FHCF's deficits is thus by and large the same as the group of individuals benefiting from the reinsurance cover offered by the FHCF.

For Citizens the situation is very different in this respect. While it is currently by far the largest direct property insurer in Florida, it is nevertheless the case that if a general assessment becomes necessary, most of the individuals having to pay this assessment are not themselves customers of Citizens. There is thus a certain amount of redistribution going on between these different groups of customers. Quantifying the extent of this redistribution is not, however, as simple as one might believe at first sight. By taking a large share of the high risk objects off the market, Citizens exerts substantial downward pressure on the level of insurance premiums (mainly for the high risks). The existence of Citizens thus has a significant positive effect even on those property owners who are not themselves Citizens customers. 
It is, of course, politically very easy to point at the "subsidised" rates Citizens customers are paying and then ask why the "average" Florida property owner should have to bear these costs. The truth is, however, somewhat more complicated. Building a house is a long term investment. Presumably, what the homeowner would like to purchase when making this long term investment decision is long term insurance cover. Unfortunately such cover is typically not available on the private market. The contracts offered by private insurance companies are usually very short term (one year). The massive premium increases and cancellations the Florida market has experienced illustrate this. While it has always been the case that the hurricane risk on the beach was higher than further inland, the extent of this risk (or its perception) has massively increased over the last decade. It is this (unexpected) increase in the (perceived) hurricane risk that has led to the massive increase in premiums.

It is perfectly valid to argue that the State should to a certain extent fill the gap left by the fact that the private insurance sector is unwilling (or unable) to offer long term cover. The most obvious way of doing this is to absorb part of the unanticipated premium increases the houseowners in the most exposed areas have to cope with. That is of course precisely the role Citizens is performing.

To summarize, Citizens (just like the FHCF) substantially reduces the pressure on the Florida hurricane insurance market by absorbing a large fraction of the most exposed risks. This should have the effect of improving the availability of cover and reducing the average premium rate for all house-owners and not just its own customers. Citizens' ability to spread its cost of risk over a large population (more than 5.7 million homeowner policies) via ex-post assessments means that it can operate with substantially lower risk premiums than private insurance companies.

The following quote indicates that the empirical magnitude of this effect is substantial: "State insurance regulators have recommended insurance companies use a 3.7 profit margin - not including income earned on investments - to calculate property insurance prices. But executives from companies such as Allstate Floridian, Nationwide and Hartford Insurance Co. of the Midwest testified that they used profit margins of 15 percent or more to calculate rate requests last year. What's more, Hartford officials said they used \$1 billion last year to buy back stock. Allstate also has bought back stock in recent years.”"16

Finally, Citizens can alleviate the burden of sudden unanticipated premium increases private insurers tend to impose on their customers. There is thus a number or very good reasons for the policy maker to continue supporting this institution.

This conclusion is sharply different to the policy recommendations one can find in the Wharton study. "..This reinforces an important point. Florida cannot rely on small or geographically concentrated insurers to underwrite a large number of homes in high risk areas. A more sustainable approach is to encourage a large number of insurers to each write a 'reasonable' number of homes in high risk areas, commensurate with the capacity and risk diversification of each company. Of course saying this is easier said than done. However, if regulators allow insurers to charge fully adequate, risk based rates and make other reasonable adjustments in their underwriting and policy terms, insurers should be more amenable to writing a manageable amount of high risk exposures” (Wharton, 2008, p 76). 
Nobody disputes that the private insurance sector would be willing to cover even the most exposed buildings in Florida if they could set sufficiently high premiums. Experience has shown, however, that the State can significantly lower the expected cost of insurance for the population as a whole by intelligently intervening in this market (where the extent of "uninsurable" risk is exceptionally high). The FHCF and Citizens are the two key institutions through which the State can achieve such improvements in market performance. The argument that similar cover can be obtained from the private market at a substantially higher cost to the customer can hardly be considered an "in-depth analysis of the efficiency of current disaster insurance markets." ${ }^{17}$

\section{F) Problems of moral hazard}

\section{a. Temptation}

As mentioned, major hurricanes may be low probability events, but they can be extremely costly. There may be several years in a row with almost no claims costs and others where they can be of the order of several billion dollars.

In principle, one could argue that if the premiums are set at an adequate rate, the insurance companies should in the "good years" be able to form sufficient reserves to cover their excess costs in the "bad years". There are, however, several problems with this general principle. First and foremost, if a company has generated more premiums than claims in any given year, at least part of this difference (the profit) legally belongs to the insurance company. While solid business practice indicates that it should set aside a large part of this surplus there is no legal obligation to do so. According to the state legislator, this is not just a theoretical possibility: "The insolvencies and financial impairments resulting from Hurricane Andrew demonstrate that many property insurers are unable or unwilling to maintain reserves, surplus, and reinsurance ${ }^{18}$ sufficient to enable the insurers to pay all claims in full in the event of a catastrophe. State action is therefore necessary to protect the public from insurer's unwillingness or inability to maintain sufficient reserves, surplus, and reinsurance."19

Given the events on the financial markets in the course of last year, one can reasonably argue that this "unwillingness to maintain sufficient reserves" seems to characterise large parts of our financial system. The massive injections of public funds into the financial sector (over US $\$ 2$ '000 billion for the US, a similar amount for the EU, CHF 68 billion just for the bank UBS etc.) is eloquent testimony to this effect. The previous decade's profits were not used to increase the reserves of the financial institutions. Rather they were distributed to shareholders and management in the form of dividends, share buy-backs and huge bonuses. The result was a substantial increase in the leverage of the financial system as a whole. The tax-payer, and the economy in general were left to foot a truly massive bill at the first significant downturn.

\section{b. Design}

The temptation to pay out dividends rather than accumulate profits is one problem. In a competitive market for catastrophe insurance one may, however, also encounter insurers who have a deliberate strategy to this effect. "Fly-by-night" insurance companies may attempt to enter the market with aggressive pricing strategies that do not allow them to cover their

Wharton (2008) Preface.

Italics by the authors.

Florida Statutes 215.555. 
effective exposure. They are then forced to leave the market when the first major event hits them. In Florida the rapid expansion of the Poe insurance company (300 million US\$ premium income in 2004) and its bankruptcy in 2005 provides a vivid illustration of this.

The Wharton study describes this episode as follows: "The story of the Poe companies is a good illustration of the 'go for broke' strategy that some insurers employ when they encounter financial difficulty. Poe insured more than 300'000 homes, with most concentrated in the high-risk areas of Palm Beach, Broward and Miami-Dade counties. Despite major losses from the 2004 storms and declining capital, Poe aggressively added more policies in 2005, gambling that it would not incur more storm losses. Such gambling is encouraged by a regulatory system, in which an insurer can shift its losses to the state (i.e. insurance companies and tax payers) through the insolvency guaranty association. The insurer reaps the potential upside of such gambles while subjecting the public to the potential downside. This scenario became reality when the Poe companies became insolvent after the 2005 storm season, generating approximately $\$ 750$ million in guaranty association assessments.” 20

This analysis is not quite correct: From the perspective of insurance companies like Poe, whether or not a guaranty association exists really makes no difference. They know that in either case they can take their profits in the "good years" and file for bankruptcy when in a "bad year"" they have insufficient funds to pay their claims. The only way to effectively prevent such behaviour is to impose a much tighter regulatory framework governing the extent of reinsurance companies have to buy and the possibilities of paying out "profits" in those years with no major event. Surprisingly the Wharton analysis does not wish to draw this conclusion.

The absence of a guaranty association would have an influence only insofar as it would force the customers to more carefully check the financial situation of the insurance company with whom they contract. Given the complexity of analysing the financial health of a real world insurance company, one may doubt whether this is really an efficient solution to the problem. One might try to argue that purchasing cover only from the larger insurance companies could help to alleviate this problem. There are two problems with this argument. First, the Wharton study strongly suggests that it is not healthy to concentrate too much of the catastrophic risk with just a few companies. Second the recent events around AIG and its US\$150 billion bailout illustrate that even large companies are by no means immune to bankruptcy. They just leave a bigger hole when they go down!

\section{Conclusion}

Florida has an exceptionally strong exposition to hurricane risk. Such risks are typically referred to as "uninsurable". The substantial increase in hurricane damage has led to a massive increase in premiums and a shortage of insurance cover for the more exposed homeowners. This increase was totally unanticipated, i.e. the homeowners are currently in the situation of having to face huge premium increases (and policy cancellations) because long term insurance cover is not available.

The Wharton study's policy suggestions, as to how Florida should cope with this situation, are of only limited scope. It is almost tautological to argue that the private insurance sector would be willing to provide cover, if only the premiums were allowed to rise fast enough.

$20 \quad$ Wharton (2008) p. 70. 
The higher the legislator allows the premiums to rise, the greater the danger that "fly-bynight" insurance companies accumulate large portfolios in a short time by offering attractive rates. They pay out part of their reserves in the forms of dividends or bonuses and then go bankrupt when a major event hits.

The State of Florida has created two institutions, the FHCF and Citizens, to partly solve these problems. Between them they take up a large chunk of the hurricane risk. Their existence substantially reduces the pressure and lowers the premiums on the private market. Their ability to charge lower premiums is based on the fact that they can cover potential deficits by resorting to assessments on all policy holders. This effectively allows them to spread the risks they take over a larger number of stakeholders.

There is every reason to believe that significantly reducing the role of these two institutions can come only at a substantial cost to the property owners as a group. The challenge is thus to fine-tune the financial terms on which they operate in such a way as to keep the political pressure the various stake holders exert at an acceptable level.

\section{$\underline{\text { References }}$}

Freeman, P.K, M. Keen and M. Mani (2003). Dealing with Increased Risk of Natural Disasters: Challenges and Options, IMF Working Paper 03/197.

Gollier, C. (2005). (2005). Some aspects of the economics of catastrophe risk insurance, in Catastrophe Risk and Insurance, OECD publishing.

Kunreuther, H. and M. Pauly (2006). Rules Rather than Discretion: Lessons from Hurricane Kathrina, Journal of Risk and Uncertainty 33:101-116.

Jaffee, D.M. and T. Russell (1997). Catastrophe Insurance, Capital Markets and Uninsurable Risks, Journal of Risk and Insurance 64(2):205-230.

Jametti, M. and T. von Ungern-Sternberg (2005). Assessing the Efficiency of an Insurance Provider - a Measurement Error Approach, The Geneva Risk and Insurance Review 30(1):1534.

Jametti, M. and T. von Ungern-Sternberg (2009). Risk Selection in Natural Disaster Insurance, IEB Working Paper 2009/6, Universitat de Barcelona.

Pollner, J.D. (2001). Catastrophe Risk Management, World Bank Policy Research Working Paper 2560.

von Ungern-Sternberg, T (2004). Efficient Monopolies: The Limits of Competition in the European Property Insurance Market, Oxford University Press.

Wharton Risk Management and Decision Process Center (2008). Managing Large-Scale Risks in a New Era of Catastrophes: Insuring, Mitigating and Financing Recovery from Natural Disasters in the United States, University of Pennsylvania. 


\section{QUADERNI DELLA FACOLTÀ}

1998:

P. Balestra, Efficient (and parsimonious) estimation of structural dynamic error component models

1999:

M. Filippini, Cost and scale efficiency in the nursing home sector : evidence from Switzerland

L. Bernardi, I sistemi tributari di oggi : da dove vengono e dove vanno

L.L. Pasinetti, Economic theory and technical progress

G. Barone-Adesi, K. Giannopoulos, L. Vosper, VaR without correlations for portfolios of derivative securities

G. Barone-Adesi, Y. Kim, Incomplete information and the closed-end fund discount

G. Barone-Adesi, W. Allegretto, E. Dinenis, G. Sorwar, Valuation of derivatives based on CKLS interest rate models

M. Filippini, R. Maggi, J. Mägerle, Skalenerträge und optimale Betriebsgrösse bei den schweizerische Privatbahnen

E. Ronchetti, F. Trojani, Robust inference with GMM estimators

G.P. Torricelli, I cambiamenti strutturali dello sviluppo urbano e regionale in Svizzera e

nel Ticino sulla base dei dati dei censimenti federali delle aziende 1985, 1991 e 1995

2000:

E. Barone, G. Barone-Adesi, R. Masera, Requisiti patrimoniali, adeguatezza del capitale e gestione del rischio

G. Barone-Adesi, Does volatility pay?

G. Barone-Adesi, Y. Kim, Incomplete information and the closed-end fund discount

$\mathrm{R}$. Ineichen, Dadi, astragali e gli inizi del calcolo delle probabilità

W. Allegretto, G. Barone-Adesi, E. Dinenis, Y. Lin, G. Sorwar, A new approach to check the free boundary of single factor interest rate put option

G.D.Marangoni, The Leontief Model and Economic Theory

B. Antonioli, R, Fazioli, M. Filippini, // servizio di igiene urbana italiano tra concorrenza e monopolio

L. Crivelli, M. Filippini, D. Lunati. Dimensione ottima degli ospedali in uno Stato federale

L. Buchli, M. Filippini, Estimating the benefits of low flow alleviation in rivers: the case of the Ticino River

L. Bernardi, Fiscalità pubblica centralizzata e federale: aspetti generali e il caso italiano attuale

M. Alderighi, R. Maggi, Adoption and use of new information technology

F. Rossera, The use of log-linear models in transport economics: the problem of

commuters' choice of mode

2001:

M. Filippini, P. Prioni, The influence of ownership on the cost of bus service provision in

Switzerland. An empirical illustration

B. Antonioli, M. Filippini, Optimal size in the waste collection sector

B. Schmitt, La double charge du service de la dette extérieure

L. Crivelli, M. Filippini, D. Lunati, Regulation, ownership and efficiency in the Swiss

nursing home industry

S. Banfi, L. Buchli, M. Filippini, Il valore ricreativo del fiume Ticino per i pescatori

L. Crivelli, M. Filippini, D. Lunati, Effizienz der Pflegeheime in der Schweiz 
2002:

B. Antonioli, M. Filippini, The use of a variable cost function in the regulation of the Italian water industry

B. Antonioli, S. Banfi, M. Filippini, La deregolamentazione del mercato elettrico svizzero e implicazioni a breve termine per l'industria idroelettrica

M. Filippini, J. Wild, M. Kuenzle, Using stochastic frontier analysis for the access price regulation of electricity networks

G. Cassese, On the structure of finitely additive martingales

2003:

M. Filippini, M. Kuenzle, Analisi dell'efficienza di costo delle compagnie di bus italiane e svizzere

C. Cambini, M. Filippini, Competitive tendering and optimal size in the regional bus transportation industry

L. Crivelli, M. Filippini, Federalismo e sistema sanitario svizzero

L. Crivelli, M. Filippini, I. Mosca, Federalismo e spesa sanitaria regionale : analisi empirica per i Cantoni svizzeri

M. Farsi, M. Filippini, Regulation and measuring cost efficiency with panel data models : application to electricity distribution utilities

M. Farsi, M. Filippini, An empirical analysis of cost efficiency in non-profit and public nursing homes

F. Rossera, La distribuzione dei redditi e la loro imposizione fiscale : analisi dei dati fiscali svizzeri

L. Crivelli, G. Domenighetti, M. Filippini, Federalism versus social citizenship :

investigating the preference for equity in health care

M. Farsi, Changes in hospital quality after conversion in ownership status

G. Cozzi, O. Tarola, Mergers, innovations, and inequality

M. Farsi, M. Filippini, M. Kuenzle, Unobserved heterogeneity in stochastic cost frontier models : a comparative analysis

2004:

G. Cassese, An extension of conditional expectation to finitely additive measures

$\mathrm{S}$. Demichelis, O. Tarola, The plant size problem and monopoly pricing

F. Rossera, Struttura dei salari 2000 : valutazioni in base all'inchiesta dell'Ufficio federale di statistica in Ticino

M. Filippini, M. Zola, Economies of scale and cost efficiency in the postal services : empirical evidence from Switzerland

F. Degeorge, F. Derrien, K.L. Womack, Quid pro quo in IPOs : why book-building is dominating auctions

M. Farsi, M. Filippini, W. Greene, Efficiency measurement in network industries : application to the Swiss railway companies

L. Crivelli, M. Filippini, I. Mosca, Federalism and regional health care expenditures : an empirical analysis for the Swiss cantons

S. Alberton, O. Gonzalez, Monitoring a trans-border labour market in view of liberalization : the case of Ticino

M. Filippini, G. Masiero, K. Moschetti, Regional differences in outpatient antibiotic consumption in Switzerland

A.S. Bergantino, S. Bolis, An adaptive conjoint analysis of freight service alternatives :

evaluating the maritime option

2005:

M. Farsi, M. Filippini, An analysis of efficiency and productivity in Swiss hospitals

M. Filippini, G. Masiero, K. Moschetti, Socioeconomic determinants of regional

differences in outpatient antibiotic consumption : evidence from Switzerland 
2006:

M. Farsi, L. Gitto, A statistical analysis of pain relief surgical operations

M. Farsi, G. Ridder, Estimating the out-of-hospital mortality rate using patient discharge data

S. Banfi, M. Farsi, M. Filippini, An empirical analysis of child care demand in Switzerland

L. Crivelli, M. Filippini, Regional public health care spending in Switzerland : an empirical analysis

M. Filippini, B. Lepori, Cost structure, economies of capacity utilization and scope in Swiss higher education institutions

M. Farsi, M. Filippini, Effects of ownership, subsidization and teaching activities on hospital costs in Switzerland

M. Filippini, G. Masiero, K. Moschetti, Small area variations and welfare loss in the use of antibiotics in the community

A. Tchipev, Intermediate products, specialization and the dynamics of wage inequality in the US

A. Tchipev, Technological change and outsourcing : competing or complementary explanations for the rising demand for skills during the 1980s?

2007:

M. Filippini, G. Masiero, K. Moschetti, Characteristics of demand for antibiotics in primary care : an almost ideal demand system approach

G. Masiero, M. Filippini, M. Ferech, H. Goossens, Determinants of outpatient antibiotic consumption in Europe : bacterial resistance and drug prescribers

R. Levaggi, F. Menoncin, Fiscal federalism, patient mobility and the soft budget constraint : a theoretical approach

M. Farsi, The temporal variation of cost-efficiency in Switzerland's hospitals : an application of mixed models

2008:

Quaderno n. 08-01

M. Farsi, M. Filippini, D. Lunati, Economies of scale and efficiency measurement in

Switzerland's nursing homes

Quaderno n. 08-02

A. Vaona, Inflation persistence, structural breaks and omitted variables : a critical view Quaderno n. 08-03

A. Vaona, The sensitivity of non parametric misspecification tests to disturbance autocorrelation

Quaderno n. 08-04

A. Vaona, STATA tip : a quick trick to perform a Roy-Zellner test for poolability in STATA Quaderno n. 08-05

A. Vaona, R. Patuelli, New empirical evidence on local financial development and growth Quaderno n. 08-06

C. Grimpe, R. Patuelli, Knowledge production in nanomaterials : an application of spatial filtering to regional system of innovation

Quaderno n. 08-07

A. Vaona, G. Ascari, Regional inflation persistence : evidence from Italy Quaderno n. 08-08

M. Filippini, G. Masiero, K. Moschetti, Dispensing practices and antibiotic use Quaderno n. 08-09

T. Crossley, M. Jametti, Pension benefit insurance and pension plan portfolio choice 
Quaderno n. 08-10

R. Patuelli, A. Vaona, C. Grimpe, Poolability and aggregation problems of regional innovation data : an application to nanomaterial patenting

Quaderno n. 08-11

J.H.L. Oud, H. Folmer, R. Patuelli, P. Nijkamp, A spatial-dependence continuous-time model for regional unemployment in Germany

2009:

Quaderno n. 09-01

J.G. Brida, S. Lionetti, W.A. Risso, Long run economic growth and tourism : inferring from Uruguay

Quaderno n. 09-02

R. Patuelli, D.A. Griffith, M. Tiefelsdorf, P. Nijkamp, Spatial filtering and eigenvector stability : space-time models for German unemployment data

Quaderno n. 09-03

R. Patuelli, A. Reggiani, P. Nijkamp, N. Schanne, Neural networks for cross-sectional employment forecasts : a comparison of model specifications for Germany

Quaderno n. 09-04

A. Cullmann, M. Farsi, M. Filippini, Unobserved heterogeneity and International benchmarking in public transport

Quaderno n. 09-05

M. Jametti, T. von Ungern-Sternberg, Hurricane insurance in Florida 